\title{
Editorial-Using Applied Economics to Study Participatory Irrigation Institutions and their Impact in South Asia
}

\author{
Lin Crase \\ UniSA Business, University of South Australia, Adelaide 5000, Australia; lin.crase@unisa.edu.au
}

Received: 13 July 2020; Accepted: 16 July 2020; Published: 20 July 2020

\begin{abstract}
For many decades, participatory approaches, with their emphasis on farmer-centred management, have been presented as panaceas for overcoming weaknesses in irrigation systems. Participatory Irrigation Management (PIM) has assumed such a high status that it is regularly mandated by donors sponsoring irrigation upgrades in poor countries. However, the success of PIM is mixed, and economic analysis can help explain why PIM might work in some settings and not in others. This Special Issue focusses on PIM and aims to scrutinise its usefulness, particularly in South Asia. The focus on South Asian irrigation is driven by the reality that smallholder agriculture is destined to be the mainstay for this most populous region, at least in the medium term, and finding solutions to raise agricultural productivity is a high priority. The Special Issue comprises nine papers employing several strands of economics, including New Institutional Economics, Game Theory, and Behavioural Economics. A synopsis of each paper is provided in this editorial.
\end{abstract}

Keywords: participatory irrigation management; south asia; applied economics

\section{Introduction}

Irrigation management in South Asia faces a confronting crossroad. Agrarian activity is still the economic mainstay for much of the region, and irrigation has long been touted as a means of providing more stable and better livelihoods for smallholders. Providing access to reliable water for crop production continues to be one of the main policy goals for most governments, but delivering on this ambition has not always been straightforward. Amongst the most vexing issues has been the efforts by governments to simultaneously improve the functioning of irrigation while having farmers play a more active role in the management of water delivery.

Arguably, there is a continuum of decision making where famers can be more (or less) involved. The literature often makes a distinction between Participatory Irrigation Management (PIM) and Irrigation Management Transfer (IMT), with the latter interpreted as a shift in ownership of irrigation assets to farmers and thus a more extreme case of "participation". In practice, Participatory Irrigation Management (PIM) and IMT are often indistinguishable, especially when PIM is seen by some as the involvement of end users in "all aspects" of irrigation management (see, [1]).

The idea of involving farmers more actively in irrigation decision making has seen the management of some parts or some functions of irrigation networks devolved to farmer groups, thereby marking a distinct contrast with the historic top-down management or irrigation by state-run bureaucracies. This general push towards devolving decisions to farmers arose in the 1980s and became a central tenet for most donor agencies thereafter. For instance, the Food and Agriculture Organisation of the United Nations (FAO) promoted an irrigation modernization program in the 1990s where technical upgrades had to be simultaneously accompanied by managerial upgrades, with a greater focus on improving resource utilization and more efficient delivery to farmers [2]. 
The relative success of PIM has been investigated over an extensive period. Many analysts noted the early trend where PIM did not to deliver the expected improvements in irrigation performance [3]. However, the overall quality of the scientific literature that deals with the relative benefits of PIM varies considerably. Although numerous studies are available (see [4] for a summary), the methodology for reporting on changes attributable to PIM generally comprises a range of "success" indicators, which are often inconsistent (see, for example, [5,6]). Most analyses are necessarily backward looking and attempt to infer what may have encouraged or limited success. Few studies attempt ex ante assessment of the uptake of PIM and, despite observations that local context is critical [7], research "has failed to dislodge Water User Associations and PIM/IMT from their pre-eminent position in irrigation reform projects and programs" ([4], p. 182).

Gaining a better understanding of what drives successful PIM remains a key issue in South Asia, with few policy alternatives on offer. Governments simply do not have the resources to adequately manage the entire irrigation network, and the political costs of mismanaged irrigation are also high. Regrettably, it is the smaller and poorer farmers who stand to lose most when surface water is not well managed. This group is often at the tail end of the network, and if deprived of water it usually does not have the financial resources to substitute groundwater. Women farmers are also often sidelined when PIM fails to function effectively.

This Special Issue of Water brings together several perspectives and empirical analyses of PIM in South Asia. Applied economics provides the analytical lens that underpins the papers.

\section{Overview of Contributed Papers}

The papers published in this Special Issue comprise nine manuscripts that fall into four main groups. The first group of papers make a theoretical contribution to scrutinizing PIM, specifically drawing on and expanding concepts related to New Institutional Economics. The second group of papers centre on empirical analysis, with each endeavoring to describe the drivers of successful PIM. The third group of papers also offer empirical insights but do so through relatively novel approaches to the PIM domain. This includes a paper based on game theory and another using discrete choice experiments. The final group of papers takes up the issue of inclusiveness in PIM, and provides analysis of gender perspectives. The papers and the categories into which they fall are summarised in Table 1. 
Table 1. Works published in the Special Issue "Using Applied Economics to Study Participatory Irrigation Institutions and their Impact in South Asia". Categories, authors, title, and topic are briefly summarised.

\begin{tabular}{|c|c|c|c|}
\hline Categories & Author & Title & Research Topic \\
\hline \multirow[t]{2}{*}{$\begin{array}{l}\text { Expansion of Concepts } \\
\text { drawn from New } \\
\text { Institutional Economics }\end{array}$} & Gandhi and Johnson (2020) & $\begin{array}{l}\text { Enhancing Performance of Participatory Water } \\
\text { Institutions in the Eastern Indo-Gangetic Plains: } \\
\text { What Can We Learn from New Institutional } \\
\text { Economics and Governance Theories? }\end{array}$ & $\begin{array}{l}\text { Expansion of New Institutional Economics to } \\
\text { Include Rationalities and Use of Ordered Probit } \\
\text { Regression to Test Framework using Indian Data }\end{array}$ \\
\hline & Crase, Cooper, and Burton (2019) & $\begin{array}{l}\text { From Sharing the Burden of Scarcity to Markets: } \\
\text { Ill-Fitting Water Property Rights and the Pressure } \\
\text { of Economic Transition in South Asia }\end{array}$ & $\begin{array}{l}\text { Considers How Historic Beneficiary/Benefactor } \\
\text { Relationships Hinders Efficient Irrigation }\end{array}$ \\
\hline \multirow[t]{3}{*}{$\begin{array}{l}\text { Empirical Analysis of PIM } \\
\text { using New Institutional } \\
\text { Economics Frameworks }\end{array}$} & $\begin{array}{c}\text { Gandhi, Johnson, Neog, and Jain } \\
(2020)\end{array}$ & $\begin{array}{l}\text { Institutional Structure, Participation, and } \\
\text { Devolution in Water Institutions of Eastern India }\end{array}$ & $\begin{array}{c}\text { Background and Case Analysis in Assam and } \\
\text { Bihar, India, Followed by Empirical Validation of } \\
\text { Relationships between Success and Institutional } \\
\text { Features }\end{array}$ \\
\hline & Johnson, Gandhi, and Jain (2020) & $\begin{array}{l}\text { Performance Behavior of Participatory Water } \\
\text { Institutions in Eastern India: A Study through } \\
\text { Structural Equation Modelling }\end{array}$ & $\begin{array}{l}\text { Structural Equation Modelling of PIM } \\
\text { Performance in Assam and Bihar, India }\end{array}$ \\
\hline & $\begin{array}{c}\text { Ahmad, Pham, Ashfaq, Memon, } \\
\text { Bano, Dahri, Mustafa, Baig, and } \\
\text { Naseer (2020) }\end{array}$ & $\begin{array}{c}\text { Impact of Institutional Features on the Overall } \\
\text { Performance Assessment of Participatory } \\
\text { Irrigation Management: Farmers' Response from } \\
\text { Pakistan }\end{array}$ & $\begin{array}{l}\text { Factor Analysis Followed by Structural Equation } \\
\text { Modelling to Explain Drivers of PIM Performance } \\
\text { in Punjab and Sindh, Pakistan }\end{array}$ \\
\hline \multirow[t]{2}{*}{$\begin{array}{l}\text { Empirical Analysis of PIM } \\
\text { using Behavioural } \\
\text { Economics }\end{array}$} & $\begin{array}{l}\text { Hone, Crase, Burton, Cooper, Gandhi, } \\
\text { Ashfaq, Lashari, and Ahmad (2020) }\end{array}$ & $\begin{array}{l}\text { Farmer Cooperation in Participatory Irrigation in } \\
\text { South Asia: Insights from Game Theory }\end{array}$ & $\begin{array}{c}\text { Development of a Game Theoretic Model to } \\
\text { Explain Noncooperation and Parameterization } \\
\text { using Survey Data on Compliance in India and } \\
\text { Pakistan }\end{array}$ \\
\hline & Burton, Cooper, and Crase (2020) & $\begin{array}{l}\text { Analysing Irrigation Farmers' Preferences for } \\
\text { Local Governance Using a Discrete Choice } \\
\text { Experiment in India and Pakistan }\end{array}$ & $\begin{array}{l}\text { Explaining Preferences for Changes to PIM using } \\
\text { Data Drawn from Pakistan and India }\end{array}$ \\
\hline \multirow[t]{2}{*}{$\begin{array}{l}\text { Gender Inclusiveness in } \\
\text { PIM }\end{array}$} & Memon, Cooper, and Wheeler (2020) & $\begin{array}{l}\text { Mainstreaming Gender into Irrigation: } \\
\text { Experiences from Pakistan }\end{array}$ & $\begin{array}{l}\text { Analysing Barriers to Women Participating in PIM } \\
\text { and the Different Perceptions of PIM Held by Men } \\
\text { and Women in Sindh and Panjab, Pakistan }\end{array}$ \\
\hline & $\begin{array}{l}\text { Khandker, Gandhi, and Johnson } \\
\text { (2020) }\end{array}$ & $\begin{array}{l}\text { Gender Perspective in Water Management: The } \\
\text { Involvement of Women in Participatory Water } \\
\text { Institutions of Eastern India }\end{array}$ & $\begin{array}{c}\text { Analyses the extent of inclusiveness in PIM in } \\
\text { Assam and Bihar, India }\end{array}$ \\
\hline
\end{tabular}




\section{Expansion of Concepts Drawn from New Institutional Economics}

Several papers draw specifically from New Institutional Economics, which has long been used to provide insights into the incentives that drive collaborative and uncollaborative behaviors around shared resources [7]. Building on concepts from New Institutional Economics, Gandhi and Johnson [8] offer an expansive framework for contemplating the influences that shape the performance of PIM. The framework comprises five key institutional features, all relating to lower transaction costs. These encompass the establishment of clear objectives, ensuring that formal and informal rules are consistent and thus creating interaction amongst water users, a degree of adaptiveness, ensuring the scope of influence is set at an appropriate scale, and a capacity to engender compliance. In addition to these institutional characteristics, Gandhi and Johnson [8] contend that performance can also be shaped by a series of measurable governance rationalities. These comprise technical, environmental, economic, social, political, organizational, financial, and government-facing elements. Using data drawn from a farmer survey deployed in India's Indo-Gangetic Plains, they subsequently operationalise their framework using Ordered Probit regression models based on Likert scale responses. Overall, they identify numerous elements of the theoretical framework that relate directly to performance under PIM.

The paper by Crase, Cooper, and Burton [9] extends the New Institutional Economics theme by shedding light on the property right dilemmas associated with irrigation in the region. They note that casting irrigation smallholders as "beneficiaries" continues to place them in a subservient role to the state-run irrigation departments who view themselves as "benefactors". They also note that this relationship is further stressed by the dynamics of agriculture, with increased efforts to diversify production creating tensions around the historic property rights regimes. PIM has the potential to mediate those tensions but requires that farmers have sufficient authority and capacity.

\section{Empirical Analysis of PIM Using New Institutional Economics Frameworks}

The extent to which farmers have authority and capacity is specifically explored by Gandhi, Johnson, Neog, and Jain [10] with a comprehensive analysis of the roll-out of PIM in two states in the north-east of India, namely, Assam and Bihar. In addition to describing the legal and institutional context in those jurisdictions, a detailed case analysis is offered of several local irrigation institutions. These sites are further explored using survey data collected from over 250 farm households in both jurisdictions. The empirical analysis of these data indicates that greater inclusion within local water institutions is positively related to success, but important caveats are also revealed. For instance, a higher representation of more privileged groups within these institutions is associated with poorer performance overall. Important qualifications are also exposed around the extent of decision making that is held locally. Notably, they find that decisions related to planning, pricing, fee collection, and water delivery drive better performance, but where local decisions are made around investments in irrigation infrastructure performance declines. These results highlight the ongoing theme that total devolution is not a panacea and local nuances matter in PIM.

The theme of devolution is further explored by Johnson, Gandhi, and Jain [11]. In this instance, they use farm household surveys from Assam and Bihar where over 50 different types of water user groups operate. Johnson, Gandhi, and Jain [11] endeavor to identify the paths of influence between key institutional criteria, a range of rationalities that describe governance and various metrics of performance. They also explore these pathways in the context of superior overall performance. The results show that overall success of the water institutions, at least as perceived by water users, is closely related to achievements in production but also influenced by equity goals and environmental successes. Johnson, Gandhi, and Jain [11] also conclude that overall success hinges on holding a degree of adaptiveness and setting boundaries at the right scale, but sound technical governance is also required.

Like Johnson, Gandhi, and Jain [11], Ahmad et al. [12] employ structural equation modelling to explore governance and institutional features related to PIM focusing specifically on the performance of local irrigation institutions in Sindh and Punjab provinces in Pakistan. Using a primary data set of over 500 farm households, they derive statistically significant factors related to the institutional 
set up and then model the interrelationships between factors and performance. Their results show that institutional factors matter. Specifically, having clear objectives, a capacity to adapt, and setting boundaries at an appropriate scale were all positively related to the performance of organizations involved in PIM. In addition, an ability to produce compliance was the most influential variable impacting performance, but local nuances between jurisdictions mean that attention to detail is also required.

\section{Empirical Analysis of PIM Using Behavioural Economics}

Diverting from the empirical modelling of institutional survey data, Hone et al. [13] harness the rationale embodied in game theory to specifically consider what would motivate farmers to be more compliant with rules established under PIM. By contemplating the farmer's decision as a potential payoff matrix, they identify both cooperative and uncooperative equilibria. Subsequently, different theoretical states are presented where farmers might potentially move from less cooperative to more cooperative behaviors. This theoretical model is built upon the assumption that farmers will be more cooperative if the monies collected to service irrigation are managed locally. If this theoretical model is parameterised using data from four jurisdictions in South Asia (Sindh and Punjab in Pakistan and Assam and Bihar in India), a complex conundrum emerges. More specifically, the results support the view that farmers will be more cooperative if more monies are managed locally, but if collection of irrigation fees is left solely in the hands of local water user groups, farmers are less likely to make voluntary payments.

The nuances of payment, collection, and local irrigation management choices are further scrutinised by Burton, Cooper, and Crase [14]. In this instance, choice experiments were undertaken to progress two main lines of inquiry. The first considered the mechanics of how irrigation fees are assessed and collected. The second related to the overall governance arrangements for the water users, including how monies would be managed, how penalties for noncompliance would be applied, and the arrangements for infrastructure maintenance. The key finding from this ambitious work was that there is considerable diversity of preferences across and within jurisdictions. As with Hone et al. [13], Burton, Cooper, and Crase [14] conclude that there is no simple universal panacea to enhancing the performance of PIM and understanding the local setting is paramount.

\section{Gender Inclusiveness in PIM}

As noted at the outset, the relative success of PIM has differential impacts on different farmer cohorts, with women farmers particularly vulnerable to dysfunctional irrigation management. Memon, Cooper, and Wheeler [15] analyse the historical context of women's participation in water affairs in Pakistan with a particular focus on the Indus basin. They note the policy ambition of mainstreaming women's participation in decision making about irrigation but also consider the practical challenges of engaging women seriously in PIM. This is done through scrutiny of over 100 surveys administered separately to men and women in the same household in Punjab and Sindh. Memon, Cooper, and Wheeler [15] identify significant differences in the perceptions of PIM across gender and locational jurisdictions. Overall, women's perceptions of the impact of farmer organizations are less sanguine than those held by men.

Similar discord between the views of men and women about PIM and water use is identified by Khandker, Gandhi, and Johnson [16]. Using the backdrop of north-east India, they analyse how farm decisions relating to water are made and the extent to which women are active participants in water user groups. They note that inclusion in water groups is far from universal and women face significant barriers to participation. Given the divergent views of men and women, there is thus a risk that PIM is overlooking important aspects of water use. There is also clear evidence from Khandker, Gandhi, and Johnson [16] that women would welcome more active involvement in PIM, especially as this represents an opportunity for enhanced status. 


\section{Conclusions}

Collectively, the papers in this issue offer useful insights into the challenges of making PIM more effective in South Asia. Clearly, government plans that promote PIM require more effort and local nuances matter a great deal. In that context, attention to detail and clear assignment of responsibilities within the capacity of individuals and groups deserve more scrutiny. There is little doubt that PIM is here to stay; there are no other feasible options for countries like India and Pakistan. Taking lessons from this Special Issue to improve the current functioning of PIM stands to significantly enhance its legacy and support broader development agendas.

Funding: The Special Issue was supported by funding form the Australian Centre for International Agricultural Research (ACIAR); grant number ADP2014/045.

Acknowledgments: I acknowledge the input of my coeditors and also thank the various referees who reviewed all the submissions.

Conflicts of Interest: The author declares no conflict of interest.

\section{References}

1. Groenfeldt, D.; Svendsen, M. Case Studies in Participatory Irrigation Management; World Bank Institute: New York, NY, USA, 2000.

2. Food and Agriculture Organization of the United Nations (FAO). Modernization of Irrigation Schemes: Past Experiences and Future Options; FAO: Rome, Italy, 2007.

3. Goldensohn, M.D. Participation and Empowerment: An Assessment of Water User Associations in Asia and Egypt; ISPAN: Arlington, VA, USA, 1994.

4. Senanayake, N.; Mukherji, A.; Giordano, M. Re-visiting what we know about irrigation management transfer: A review of the evidence. Agric. Water Manag. 2015, 149, 175-186. [CrossRef]

5. Gandhi, V.; Namboodiri, N. Improving Irrigation Management in India: A Study of Participatory Irrigation Management in the States of Andhra Pradesh, Gujarat and Maharashtra; Allied Publishers: New Delhi, India, 2011.

6. Bewer, J; Kolavalli, S.; Karlo, G.; Naik, G.; Ramamnarayan, S.; Raju, K.; Sakthivadivel, R. Irrigation Management Transfer: Policies, Processes and Performance; IBH Publishing Company: New Delhi, India, 1999.

7. Ostrom, E. Governing the Commons: The Evolution of Institutions for Collective Action; Cambridge University Press: Cambridge, UK, 1990.

8. Gandhi, V.P.; Johnson, N. Enhancing performance of participatory water institutions in the eastern Indo-Gangetic plains: What can we learn from new institutional economics and governance theories? Water 2020, 12, 70. [CrossRef]

9. Crase, L.; Cooper, B.; Burton, M. From sharing the burden of scarcity to markets: Ill-fitting water property rights and the pressure of economic transition in South Asia. Water 2019, 11, 1294. [CrossRef]

10. Gandhi, V.P.; Johnson, N.; Neog, K.; Jain, D. Institutional structure, participation, and devolution in water institutions of Eastern India. Water 2020, 12, 476. [CrossRef]

11. Johnson, N.; Gandhi, V.P.; Jain, D. Performance behavior of participatory water institutions in Eastern India: A study through structural equation modelling. Water 2020, 12, 485. [CrossRef]

12. Ahmad, B.; Pham, H.D.; Ashfaq, M.; Memon, J.A.; Bano, R.; Dahri, Z.H.; Mustafa, R.N.; Baig, I.A.; Naseer, M.A.R. Impact of institutional features on the overall performance assessment of participatory irrigation management: Farmers' response from Pakistan. Water 2020, 12, 497. [CrossRef]

13. Hone, S.; Crase, L.; Burton, M.; Cooper, B.; Gandhi, V.P.; Ashfaq, M.; Lashari, B.; Ahmad, B. Farmer cooperation in participatory irrigation in South Asia: Insights from game theory. Water 2020, 12, 1329. [CrossRef]

14. Burton, M.; Cooper, B.; Crase, L. Analyzing irrigation farmers' preferences for local governance using a discrete choice experiment in India and Pakistan. Water 2020, 12, 1821. [CrossRef] 
15. Memon, J.A.; Cooper, B.; Wheeler, S. Mainstreaming gender into irrigation: Experiences from Pakistan. Water 2019, 11, 2408. [CrossRef]

16. Khandker, V.; Gandhi, V.P.; Johnson, N. Gender perspective in water management: The involvement of women in participatory water institutions of Eastern India. Water 2020, 12, 196. [CrossRef]

(C) 2020 by the author. Licensee MDPI, Basel, Switzerland. This article is an open access article distributed under the terms and conditions of the Creative Commons Attribution (CC BY) license (http://creativecommons.org/licenses/by/4.0/). 